\section{Information Ethics As An Important Factor In The Digital Society}

Tilavova Umida Kakhramonovna,

Navai State Pedagogical Institute, Uzbekistan

\author{
G OPEN ACCESS \\ The American Journal of \\ Social Science And \\ Education Innovations \\ JULY 2020 \\ Page No.: 204-207 \\ Volume-II Issue-VII \\ PUBLISHED: 30 JULY 2020 \\ www.usajournalshub.com/inde \\ x.php/tajssei \\ Copyright: Original content \\ from this work may be used \\ under the terms of the \\ Creative Commons Attribution \\ 4.0 licence.
}

\title{
Abstract
}

This article discusses the concept of information ethics, which deals with the study of ethical issues that arise in today's information societies. It also highlights its importance, principles and classification in the life of society.

Keywords: Information ethics, information technology, Parhezia, intellectual property, respect, responsibility, norms

\section{Introduction}

We live in a society that is radically different from our ancestors. This new view of the world is also radically changing the way people perceive. Concepts such as "information", "information technology" cover all spheres of social life. of course. We do not deny the positive side of this process. However, in the process of shaping the global information environment, ethical norms and values are also moving away from their essence, and today the problem of alienation of people from it is becoming increasingly relevant. In this regard, the analysis of the impact of information communication problems on man, his morality has become a need of practical philosophy in today's world.

It is known from history that moral concepts are a social phenomenon that evolves and changes as society changes. Also, in today's information societies, with the growing use of information technology and products, traditional ethical views in human activity have begun to enter a new phase in a sense. Now the traditional ethical principles that existed before began to require a new approach in solving the modern ethical problems that have arisen today. In this sense, the field of ethics that governs and regulates the behavior of those who operate in the information space, that is, information producers and 
consumers, has been called Information Ethics. The ethical issues arising from these changes are recognized as the object of study of information ethics.

\section{The Main Findings And Results}

The most pressing new types of ethical issues we face at every step and require attention are related to the use and development of information technologies, which play an important role in all areas. Decades ago, it was unthinkable that information technology would radically change a person's worldview, lifestyle, and this in turn would lead to a number of ethical problems. As a result, the principles of moral demand that previously existed in societies began to require a new approach in modern society, which is now emerging. Because, given the growing influence of information technology on human life in recent years, such an impact is not limited to the scientific, political, military, industrial spheres, but has now become an important factor in the dynamics of social development of all mankind. In other words, digital technologies have become not only a simple tool for carrying out human behavior, but also an integral part of his attitude towards the environment. As a result, the development and widespread dissemination of information technology in this way has also accelerated the pace of development of informed societies. And, of course, the continuous development of information technology, which is the basis of such a new society, has also had a significant impact on people's moral relationships, and this impact is reflected in the following:

1. The impact of information technology on interpersonal relationships. It is known that in today's society, due to the popularity of instant communication and the unprecedented expansion of the use of social networks, direct interaction between people has significantly decreased. Instead, the process of indirect communication between them is evolving. And unfortunately, this type of relationship is very fast and often devoid of human qualities, creating certain difficulties in evaluating and controlling the behavior of the parties in terms of existing traditional ethical norms.

2. The origin of the conflict between information production and information exchange. With the advent of new technologies, it has become much easier and cheaper to reproduce and distribute information materials by copying, scanning, or otherwise performing them on information. But there is another side to the issue that this ease of information reproduction has in many cases led to a certain conflict between consumers who want to use information as cheaply as possible and those who have intellectual property rights. And the inability to regulate these contradictions through traditional moral norms has created some complications.

In today's fast-paced world, information is invaluable in the decision-making process of our daily lives, as well as in the growth and development of society. Even without reliable and timely information, we imagine that we will face great difficulty in making decisions and planning our activities. We are no longer concerned about the lack or lack of information, on the contrary we are confused in understanding and comprehending them due to the excess of information. Admittedly, it is becoming increasingly difficult for each of us to use the information that is being disseminated in an unprecedented way. In the same process, it is emphasized that information ethics helps us to solve problems in the effective use of information.

Given that information ethics is a broad field, its object of study is also interpreted in two different ways. Experts say it deals with ethical issues related to the internet in a 
narrow range. In a broad sense, this concept aims to ethically reconsider all the phenomena that cover the problems of the digital world.

Based on the research, it can be said that although the term information ethics originated in the twentieth century with the advent of the computer and the internet, its roots go back a long way. In this regard, experts believe that information ethics has a long and recent history. Although its recent history is explained in connection with the emergence and development of modern information technologies, especially the Internet, given that humanity has been a major subject of the information exchange process since its inception, the roots of this concept go back a long way. In this sense, Western scholars have linked the emergence of information ethics to the activities of "freedom of speech" (Parhezia), or "truth-tellers" in ancient Greece. Emphasizing that this connection is also directly related to the philosophy of Socrates, they rely on the idea that any freedom of speech in the philosophy of Socrates in this matter should be based on the ethical principle of "telling the truth". Athenian democracy was also based on the freedom of speech to act as a "truth-teller" to any "good" citizen. Since "telling the truth" is one of the preconditions of morality in any time and place, it can be said that "Parrhezia" is one of the historical roots of the field of information ethics today.

As for the emergence of the term information ethics, some ideas about this term were first developed in the 1980s by Barbara Kostrewski and Ch. Mentioned by Oppenhim in an article published in the journal Information Science. This is further detailed in R. Capurro's 1988 article "Information Ethos and Information Ethics" in Germany and in 1992 in R. Hauptman's article "Ethical Changes in Libraries."

When it comes to the principles of information ethics, it does not require the discovery of new principles, but rather the reconsideration and adaptation of existing ethical principles from the perspective of the information society. In this context, the following are the most general principles of information ethics:

1.Respect: This most important principle reflects the attitude of the information consumer in the process of information activity, first of all, to himself and also to other people. And this attitude means respect for the personality of others, for their diverse lives, worldviews, intellectual property, potential, privacy. Unfortunately, we cannot say that this principle is followed by every operator of the Internet world today. The reason is that in today's virtual world, the spread of various false information about the personal and social lives of others is growing, and as a result, we unknowingly endanger the lives of others, which shows the importance of this principle.

2. Responsibility: This principle is to form a sense of responsibility for any of our actions in the process of operating in the infosphere. The information we spread that we don't care about can actually have a negative impact on someone's personal life, their professional activities. Therefore, in cyberspace, it is advisable for information users to carefully consider the consequences of their actions and implement the consequences with ethical analysis.

3. Impartiality: In the virtual world, everyone must be convinced for the authenticity, objectivity, completeness and accuracy of the information they provide, and must not violate the fundamental freedoms and rights of others. 
4. Norm: Telecommunications and the Internet should be used in an acceptable time frame and, of course, limited in time so that the impact on real life is not excessive. Otherwise, a person who is overly attached to the virtual world may forget their existing tasks in real life and develop a feeling of indifference to what is happening in the environment.

5. Attentive attitude: In order to create a healthy ethical environment in the infosphere, it is advisable for each information user to pay close attention to their activities. On the other hand, it requires you to be more attentive to the messages (calls, sms, audio, video, etc.) sent by your loved ones, acquaintances, colleagues. In most cases, leaving their messages unanswered can be seen as disrespectful, irresponsible.

Various studies have analyzed a number of areas of information ethics. We consider it expedient to give the following classification in its most general sense:

1. Internet ethics;

2. Computer ethics;

3. Media ethics (media ethics);

4. Mobile ethics

\section{Conclusion}

Information-related civilization has radically changed not only the socio-cultural space, but also human thinking and lifestyle accordingly, forming a new term in this field called information ethics. This concept itself is very multifaceted and is used in a variety of senses. It also encourages a person to establish a completely new relationship with the outside world. In our view, information ethics serves as a key factor in helping to overcome the ethical challenges that may arise in modern societies that are informed. At the same time, it can be said that the information processes of such societies control the development processes related to informatization in terms of ethical requirements. In this context, information ethics has a special role in the formation of modern ethical norms related to information activities, while preserving the traditional moral values and priorities in human life.

\section{References}

1. Rafael Capurro. Towards an ontological foundation of information ethics.2018y,

2. Thomas Froehlich. A brief history of information ethics. Universitat de Barcelona. Facultat de Biblioteconomia i Documentació 2004

3. Floridi L. Information ethics: On the philosophical foundations of computer ethics. 2009. URL: http://www.philosophyofinformati@ on.net/publications/pdf/ieotfce.pdf (date of the application: 24.09.2009).

4. E.V. Koval Ethics of the information society as a modern stage in the development of ethics / E.V. Koval // Bulletin of the Chuvash University. - 2009. - No. 4. - pp. 133-139.

5. Ethics in the Information Society: The Nine 'P's. A Discussion Paper for the WSIS +10 Process 2013-2015, Globethics.net Texts 4, Geneva 2013, - p. 32. Download for free: www.globethics.net/publications. 